\title{
Mineralization of organic nitrogen and carbon (fish food) added to anoxic sediment microcosms: role of sulphate reduction
}

\author{
Lars Stenvang Hansen ${ }^{1}$, Marianne Holmer ${ }^{2}$, Thomas Henry Blackburn ${ }^{1}$ \\ 'Department of Microbial Ecology, University of Aarhus, Ny Munkegade, DK-8000 Aarhus C., Denmark \\ ${ }^{2}$ Institute of Biology, University of Odense, Campusvej 55, DK-5230 Odense M., Denmark
}

\begin{abstract}
Substrate (fish food) was added to gas-tight bags containing sediment, with and without molybdate. Amino-nitrogen (amino-N) was measured by high-performance liquid chromatography. The oxidation of 3 representative ${ }^{14} \mathrm{C}$-labelled amino acids (glutamic acid, alanine and arginine) was measured and the mean decay rate constant was used to calculate turnover rates of amino-N. Concentrations of dissolved organic nitrogen, dissolved organic carbon, total inorganic carbon and ammonium were measured during $28 \mathrm{~d}$ of incubation. Inhibition of sulphate-reducing activity gave a 4.2 -fold decrease in the rate of ammonium production and a 4.5 -fold decrease in the rate of amino acid turnover. These results suggest an active participation of sulphate-reducing bacteria in amino acid oxidation.
\end{abstract}

KEY WORDS: Ammonium production - DFAA - Dissolved organic nitrogen (DON) - Sulphate reduction

\section{INTRODUCTION}

Only a few years ago it was questioned whether sulphate-reducing bacteria could degrade amino acids in marine sediments. However, recent investigations have shown a probable involvement (Burdige 1989, 1991, Parkes et al. 1989). Smith \& Klug (1981) reported that sulphate reduction accounted for $85 \%$ of the dissolved free amino acid (DFAA) oxidation in lake sediment. Henrichs \& Farrington (1987) and Burdige \& Martens (1990) found amino acid degradation in sediment strata dominated by sulphate reduction as the main oxidative process

This study examined the dynamics of organic nitrogen and carbon in a sediment with high sulphatereducing activity, and the importance of sulphatereducing bacteria in amino-nitrogen (amino-N) oxidation was evaluated.

\section{MATERIALS AND METHODS}

Sampling area. Sediment was sampled (from 0 to $5 \mathrm{~cm}$ depth) in October 1992 below a marine fish farm situated in Kolding Fjord (Holmer \& Kristensen 1992). In the farming season (April-October) the fish (rainbow trout Oncorhynchus mykiss) were intensively fed; fish food and faeces made the underlying sediment anoxic in that period. The bottoms of the cages were $1 \mathrm{~m}$ above the sediment surface.

Water temperature varied between 4 and $20^{\circ} \mathrm{C}$ and the salinity from 15 to $24 \%$, depending on water exchange in the fjord.

Experimental procedure. The sediment was homogenised and preincubated anoxically in gas-tight polyester/polythene bags (Ril-O-Ten $80 / 160$ ) for $7 \mathrm{~d}$ at $5^{\circ} \mathrm{C}$ before the start of the experiment.

Each bag contained $1 \mathrm{l}$ of sediment. Four types of incubations were done: controls $-1+$ molybdate $(\mathrm{C}-$ and $C M$ incubations respectively) and bags to which substrate was added - / molybdate ( $\mathrm{S}-$ and SM incubations respectively). Molybdate was used as a specific and effective inhibitor of sulphate reduction (Oremland \& Capone 1987). In the substrate bags, $2.8 \mathrm{~g}$ of homogenised fish food pellets (ECOLINE 19, Dansk Ørredfoder) was added. The bags were mixed carefully and subsamples were removed for analysis. Addi- 
tional sulphate was added to the bags to give an initial concentration of $50 \mathrm{mM}$, which was also the concentration of molybdate in the CM and SM incubations. The experiment was run for $28 \mathrm{~d}$. The high metabolic activity of the sediment was controlled by reducing the temperature of incubation to $5^{\circ} \mathrm{C}$.

Microbiological and chemical analysis. DFAAs in $0.2 \mu \mathrm{m}$ filtered (Sartorius Minisart NML) pore water were analysed by high-performance liquid chromatography (HPLC; Waters Chromatographic System) of o-phthaldialdehyde-derivatized products (Lindroth \& Mopper 1979, Mopper \& Dawson 1986)

Mineralization of DFAA was measured by adding $100 \mu \mathrm{l}{ }^{14} \mathrm{C}$-labelled $(0.01 \mu \mathrm{Ci})$ alanine, glutamic acid and arginine uniformly to separate $5 \mathrm{~cm}^{3}$ subsamples giving final ${ }^{14} \mathrm{C}$-DFAA concentration at about 14,8 and $7 \mathrm{nM}$ respectively. The incubation during a $2 \mathrm{~h}$ timecourse experiment was stopped at specific time intervals by adding $2 \mathrm{ml} 1 \mathrm{~N} \mathrm{NaOH}$. Mineralization was measured as ${ }^{14} \mathrm{CO}_{2}$ was produced, collected by microdiffusion (Lund \& Blackburn 1989) and radioactivity counted on a Packard 2200 CA Liquid Scintillation Analyzer. Total hydrolysable amino acids (THAA) was measured on $\mathrm{HCl}$-hydrolysed sediment (Burdige \& Martens 1988). Dissolved organic nitrogen (DON) was measured in $0.2 \mu \mathrm{m}$ filtered pore water and analysed on an Antek 7000 Elemental N-Analyzer. Particulate organic $\mathrm{C}$ and $\mathrm{N}$ (POC and PON respec-

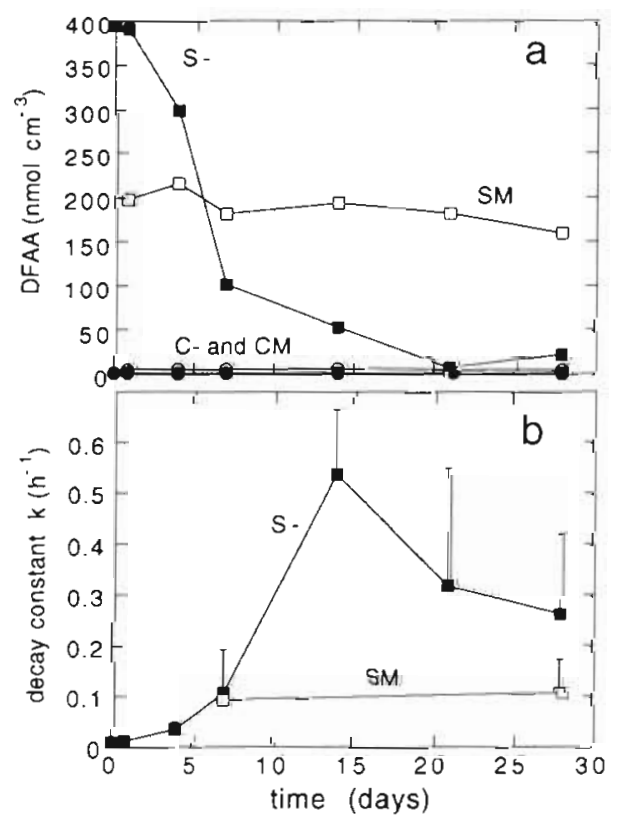

Fig. 1. (a) DFAA concentrations of substrate without molybdate $\left(S_{-}, \mathbf{D}\right)$, substrate with molybdate (SM, $\left.\square\right)$, control without molybdate $(\mathrm{C}-\bullet)$ ), and control with molybdate $(\mathrm{CM}, \mathrm{O})$ incubations. (b) Decay-constants for S- and SM as a function of incubation time ( +1 SD for the 3 amino acids used) tively) in the sediment and the added substrate were measured on a Carlo Erba Elemental Analyzer EA 100A. Total exchangeable $\mathrm{NH}_{4}^{+}$was obtained by extraction of $5 \mathrm{~cm}^{3}$ of sediment in $5 \mathrm{ml} 1 \mathrm{~N} \mathrm{KCl}$ and measured according to Solórzano (1969). Dissolved organic carbon (DOC) was measured on a Shimadzu TOC-5000 analyzer and total $\mathrm{CO}_{2}\left(\mathrm{TCO}_{2}\right)$ was analyzed by potentiometric Gran titration (Talling 1973). The sulphate reduction was estimated by the integrated rate of sulphate disappearance. Sulphate was analysed by UV-detection on a Kontron Ion Liquid Chromatograph with $2.5 \mathrm{mM}$ potassium hydrogen phthalate $(\mathrm{pH}=4.5)$ as eluent. Volatile fatty acids were measured by the HPLC methods of Bøtte (1992) modified for seawater analysis.

The measurements of DFAA, DON and $\mathrm{NH}_{4}{ }^{+}$are presented as a mean of 2 replicates. The standard deviations were negligible and are not shown.

\section{RESULTS}

The sediment was rich in organic matter [ $17 \%$ of dry weight (loss-on-ignition)] and the content of POC and PON in the sediment for the experiment was 1225 and $83 \mu \mathrm{mol} \mathrm{cm}{ }^{-3}$ respectively. The THAA content in the beginning of the experiment was $45 \mu \mathrm{mol} \mathrm{cm}{ }^{-3}$ sediment and decreased slightly towards the end of the experiment. The water salinity at the time of sampling was $15 \%$, and the $\mathrm{pH}$ in pore water in the experimental period was constant (ca 7).

The added substrate increased the organic $\mathrm{C}$ and $\mathrm{N}$ content by approximately 136 and $15 \mu \mathrm{mol} \mathrm{cm}^{-3}$ respectively. Of this, THAA was only ca $6 \%$ by weight; alanine, glutamic acid and arginine contribution to THAA was by 18,11 , and $3 \%$ respectively. The acidhydrolysable volatile fatty acid content in the substrate consisted of formate, acetate and propionate, giving initial pore water concentrations of ca 2.0, 2.1 and $0.1 \mathrm{mM}$ respectively, assuming they had been totally dissolved in the pore water. The $\mathrm{C} / \mathrm{N}$ ratio in the substrate was 8.4

The pore water content of DFAA (Fig. 1a) was very different in the 4 incubation types. The $\mathrm{C}$ - concentration was relatively stable ( 1 to $2 \mathrm{nmol} \mathrm{cm}^{-3}$ ), and was 4 times lower than the CM concentration. In $\mathrm{S}$ - the DFAA was high initially, $395 \mathrm{nmol} \mathrm{cm}^{-3}$, because of the organic loading, decreasing dramatically during the first $10 \mathrm{~d}$ and finally reached a level 4 times that of the control. The concentration was initially lower in SM and decreased slightly towards the end of experiment. The course of the individual amino acids generally followed the curves for total DFAA.

The DFAA mineralization rates were based on the decay constant (Fig. 1 b) $\mid k=\ln \left({ }^{14} \mathrm{C}\right.$-amino acid $-{ }^{14} \mathrm{CO}_{2}$ 
produced)] multiplied by the concentration of the respective amino acid. The $k$ value in $\mathrm{S}$ - increased to $0.53 \mathrm{~h}^{-1}$ over the first $15 \mathrm{~d}$, and fell gradually towards the end of the experiment (Fig. 1b). The decay constants in SM were only measured on 2 occasions (after 15 and $28 \mathrm{~d}$ ). These values were at the same level $\left(0.1 \mathrm{~h}^{-1}\right)$. All decay constants were based on the mean value of decay constants for alanine, glutamic acid and arginine and may not be a correct mean of all the DFAA represented in the pore water. Data for the control bags are shown in Table 1 (mean value).

The concentration changes in DON are shown in Fig. 2a. The S-concentrations decreased over the first $10 \mathrm{~d}$, similar to the decrease in DFAA, and stabilised at 217 to $260 \mathrm{nmol} \mathrm{cm}{ }^{-3}$. The DON concentrations in the C- incubation were constant at 17 to $52 \mathrm{nmol} \mathrm{cm}^{-3}$. Molybdate treatment had no significant effect. In the S- incubation $32 \%$ of the THAA added in substrate was measured initially as DON.

DOC in the controls was ca $1 \mu \mathrm{mol} \mathrm{cm} \mathrm{cm}^{-3}$ and varied

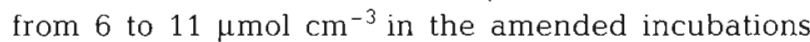
(Fig. 2b). In $\mathrm{S}_{-}$, the progress of DON and DOC indicated the substrate to be refractory, and was probably liberated enzymatically.

In all 4 types of incubation, the concentration of $\mathrm{NH}_{4}{ }^{+}$ increased in the $\mathrm{KCl}$ extraction (Fig. 3a). The rates in $\mathrm{S}-$ and SM were quite different, 185 and $44 \mathrm{nmol} \mathrm{cm}^{-3}$ $\mathrm{d}^{-1}$ respectively, as a consequence of the molybdate addition. S- and SM rates had a tendency to decrease after $7 \mathrm{~d}$ of incubation, as did the pore water $\mathrm{NH}_{4}{ }^{+}$(data not shown). The ratio between $\mathrm{KCl}$ extracted and pore water $\mathrm{NH}_{4}{ }^{+}$was approximately $1: 1$.

The $\mathrm{TCO}_{2}$ concentration increased gradually in the $\mathrm{C}$ - incubation (ca $0.25 \mu \mathrm{mol} \mathrm{cm} \mathrm{cm}^{-3} \mathrm{~d}^{-1}$ ), whereas in Sthere was a tendency to stabilise towards Day 12 , followed by a linear increase at a rate of $1.6 \mu \mathrm{mol} \mathrm{\textrm {cm } ^ { - 3 }}$ $\mathrm{d}^{-1}$ (Fig. 3b). $\mathrm{TCO}_{2}$ was not measured in the molybdate bags.

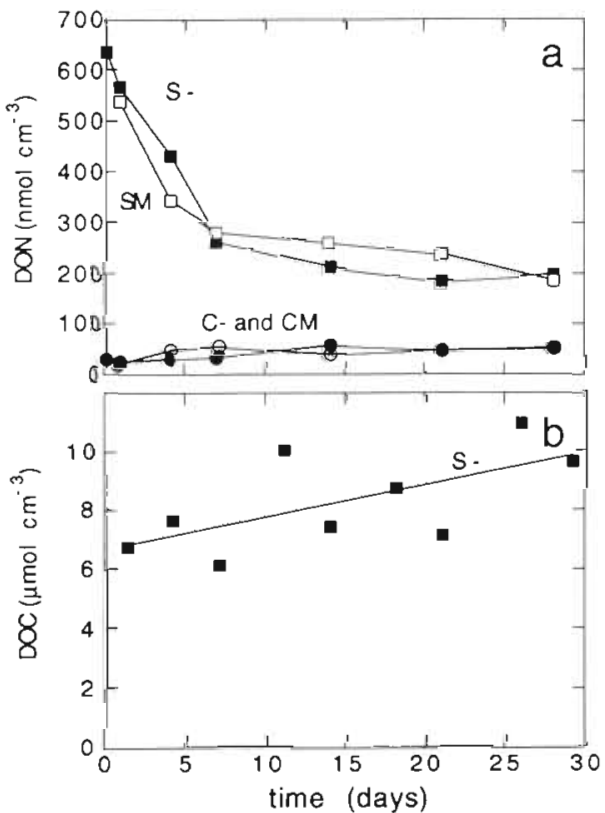

Fig. 2. Concentrations of (a) dissolved organic nitrogen (DON) in S-, SM, C- and CM and (b) dissolved organic carbon (DOC) in $\mathrm{S}-$ as a function of incubation time. Symbols as in Fig. 1

\section{DISCUSSION}

The added substrate had a large effect on the measured rates which showed that the sediment had a considerable potential for organic degradation. Similarly, other experiments indicated that sediment bacterial activity responded within a few hours after being supplied with fresh organic matter (Hansen \& Blackburn 1991, 1992).

The substrate, partially because of the high content of free amino acids, produced an initially high concentration of DFAA in the pore water, at least in $\mathrm{S}-$

Table 1. Dissolved free amino acid (DFAA) concentrations and mineralization rates, and production of ammonium and total $\mathrm{CO}_{2}$ $\left(\mathrm{TCO}_{2}\right)$, resulting from incubations with and without molybdate. Mineralization rates were calculated by multiplying the decay constant $(k)$ by the DFAA concentration. All calculations were done from Days 7 to 28 . S-: Substrate incubated without molybdate; SM: substrate with molybdate; $\mathrm{C}-$ : control without molybdate; $\mathrm{CM}$ : control with molybdate; nd: not determined

\begin{tabular}{|c|c|c|c|c|c|}
\hline $\begin{array}{l}\text { Type of } \\
\text { incubation }\end{array}$ & 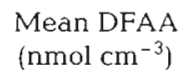 & $\begin{array}{c}k \\
\left(d^{-1}\right)\end{array}$ & $\begin{array}{l}\text { DFAA-N mineralization } \\
\text { rate }\left(\mathrm{nmol} \mathrm{cm}^{-3}\right)\end{array}$ & $\begin{array}{l}\text { Mean } \mathrm{NH}_{4}{ }^{+} \text {prod. } \\
(\text { nmol cm } \\
\left.\mathrm{cm}^{-3} \mathrm{~d}^{-1}\right)\end{array}$ & $\begin{array}{l}\text { Mean } \mathrm{TCO}_{2} \text { prod. } \\
\left(\mathrm{nmol} \mathrm{cm} \mathrm{cm}^{-3} \mathrm{~d}^{-1}\right)\end{array}$ \\
\hline S- & 33 & 7.2 & 238 & 185 & 1642 \\
\hline $\mathrm{SM}$ & 156 & 2.4 & 376 & 44 & nd \\
\hline $\mathrm{SM}^{a}$ & 22 & 2.4 & 53 & nd & nd \\
\hline C- & 1.2 & 4.4 & 5.5 & nd & 242 \\
\hline $\mathrm{CM}$ & 5.2 & 2.0 & 10.5 & nd & nd \\
\hline$C M^{a}$ & 0.9 & 2.0 & 1.8 & nd & nd \\
\hline
\end{tabular}




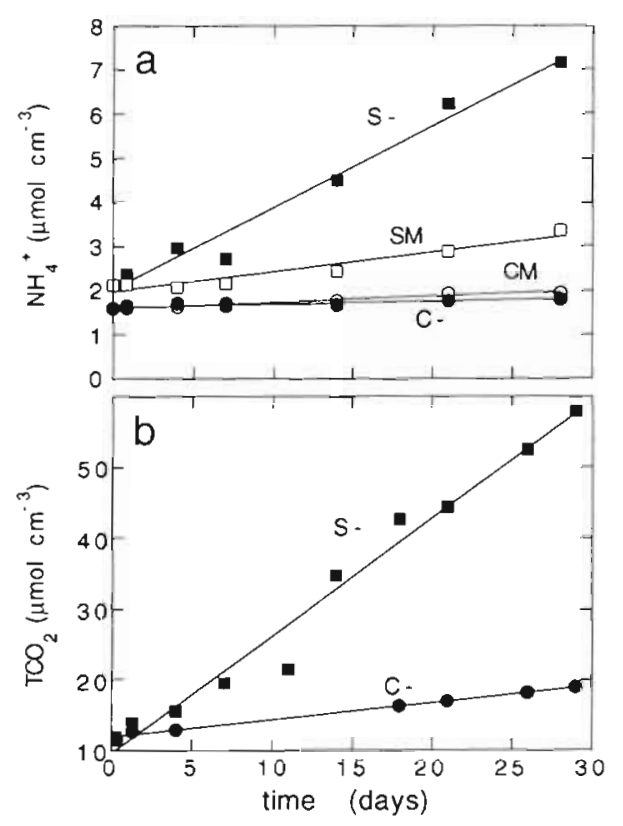

Fig. 3. Concentrations of (a) $\mathrm{NH}_{4}{ }^{+}$in $\mathrm{S}-, \mathrm{SM}, \mathrm{C}-$ and $\mathrm{CM}$ and (b) $\mathrm{TCO}_{2}$ in $\mathrm{S}-$ and $\mathrm{C}-$ as a function of time. Symbols as in Fig. 1

(Fig. 1a). The first measurements in SM were taken after $1.5 \mathrm{~d}$, possibly explaining the low concentration at that time, but it is likely that other factors were also involved. The DFAA concentration decreased throughout the incubation in $\mathrm{S}_{-}$, but remained constant in SM.

The decay constant $(k)$ increased in $\mathrm{S}-$, consistent with bacterial growth, but the $k$ value apparently began to fall after $15 \mathrm{~d}$. (Fig. $1 \mathrm{~b}$ ). The $k$ values for SM were lower and did not change during incubation.

In $\mathrm{S}$ - the changes in DFAA were parallel to changes in DON over the first $10 \mathrm{~d}$ (Fig. 2a), but in SM the fall in DON was not reflected in a decrease in DFAA. In $\mathrm{SM}$, amino-N constituted $70 \%$ of the DON; in $\mathrm{S}-$, the amino content was initially only $30 \%$ of DON and decreased during incubation. There was evidence that SM contained unidentified amino compounds accumulating from the start of the experiment (Fig. 4); the mean value of amine- 2 was $35 \%$ of the total amino-N. None of these compounds were present in the original substrate. They were different from the protein amino acids in Sigma AA-S-18 amino standard solution, and from the non-protein $\beta$-alanine, $\alpha$ and $\gamma$-amino-butyric acid, $\beta$-amino-glutaric acid, urea and methyl amine. Possibly they were primary amines derived from amino acids by decarboxylation. The original substrate contained much taurine which disappeared in $\mathrm{S}$-, but not in SM and to our knowledge degradation of taurine has not previously been described in marine sedi- ments. There was thus evidence for composition changes in the amino compounds during incubation, a fact which is relevant to the calculation of total amino turnover. This turnover rate was calculated from the mean decay constant of 3 amino acids (alanine, glutamic acid and arginine) multiplied by the total amino pool (Table 1). However, alanine is expected to be easily decomposable, whereas results from other experiments and our own experience have shown that glutamic acid and arginine were more refractory (Christensen \& Blackburn 1980, Burdige 1991, Sugai \& Henrichs 1992). If this mean $k$ value was not representative of the amino compounds present at different times, an error in the total turnover would result. It is possible that this occurred, as there was an apparent fall in the mean $k$ value after an initial rise. This fall occurred after $15 \mathrm{~d}$, at a time when $\mathrm{NH}_{4}{ }^{+}$production was still evident (Fig. 3a). In practice, a precise $k$ constant and DFAA mineralization rates are difficult to measure because we do not know if the total measurable DFAA pools are completely accessible for microbial decomposition. Furthermore, the DFAAs have a great affinity to binding sites in the sediment (Hedges \& Hare 1987, Henrichs \& Farrington 1987), and a large part of added ${ }^{14} \mathrm{C}$-amino acid 'disappears' and is slowly liberated (Christensen \& Blackburn 1980, Burdige \& Martens 1990, Burdige 1991, Sugai \& Henrichs 1992). We do not know if this pool was accessible in the course of our experiment. Non-availability underestimates the rates significantly. Test experiments in different sediments showed that e.g. alanine (neutral) and arginine (basic) were adsorbed up to 15 and $80 \%$ respectively.

The calculated mean turnover of amino- $\mathrm{N}$ in $\mathrm{S}-\mathrm{was}$ $238 \mathrm{nmol} \mathrm{cm}^{-3} \mathrm{~d}^{-1}$ while $\mathrm{NH}_{4}{ }^{+}$production was 185 nmol $\mathrm{cm}^{-3} \mathrm{~d}^{-1}$ (Table 1). This indicated that all, or a large portion, of $\mathrm{NH}_{4}{ }^{+}$was produced by amino acid mineralization. The high concentration of amino- $N$ (not identified) in SM gave a high calculated mean turnover of $376 \mathrm{nmol} \mathrm{cm} \mathrm{cm}^{-3}$ which is clearly too high in relation to the rate of $\mathrm{NH}_{4}{ }^{+}$production $\left(44 \mathrm{nmol} \mathrm{cm}{ }^{-3}\right.$ $\mathrm{d}^{-1}$ ). When the amino nitrogen which was not mineralized (taurine) or which accumulated (amine- 1 and amine-2) in SM were subtracted from the amino pool,

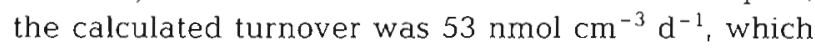
was very close to the $\mathrm{NH}_{4}{ }^{+}$production rate $(44 \mathrm{nmol}$ $\mathrm{cm}^{-3} \mathrm{~d}^{-1}$ ). The concentrations of amine-1 and amine-2 decreased towards the end of the experiment possibly due to bacterial adaptation. A similar situation occurred in the control incubations where the turnover

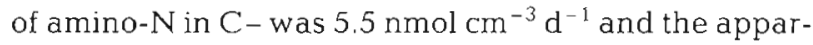

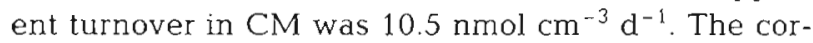
rected value for $C M$ was reduced to $1.8 \mathrm{nmol} \mathrm{cm}^{-3} \mathrm{~d}^{-1}$. To our knowledge, no larger contribution by sulphatereducing bacteria to $\mathrm{NH}_{4}^{+}$production has been 
Fig. 4. Concentrations of taurine, amine- 1 and amine- 2 in the controls ( $a$ to $c$ ) and in the substrate-added bags (d to f) as a function of time. Symbols as in Fig. 1

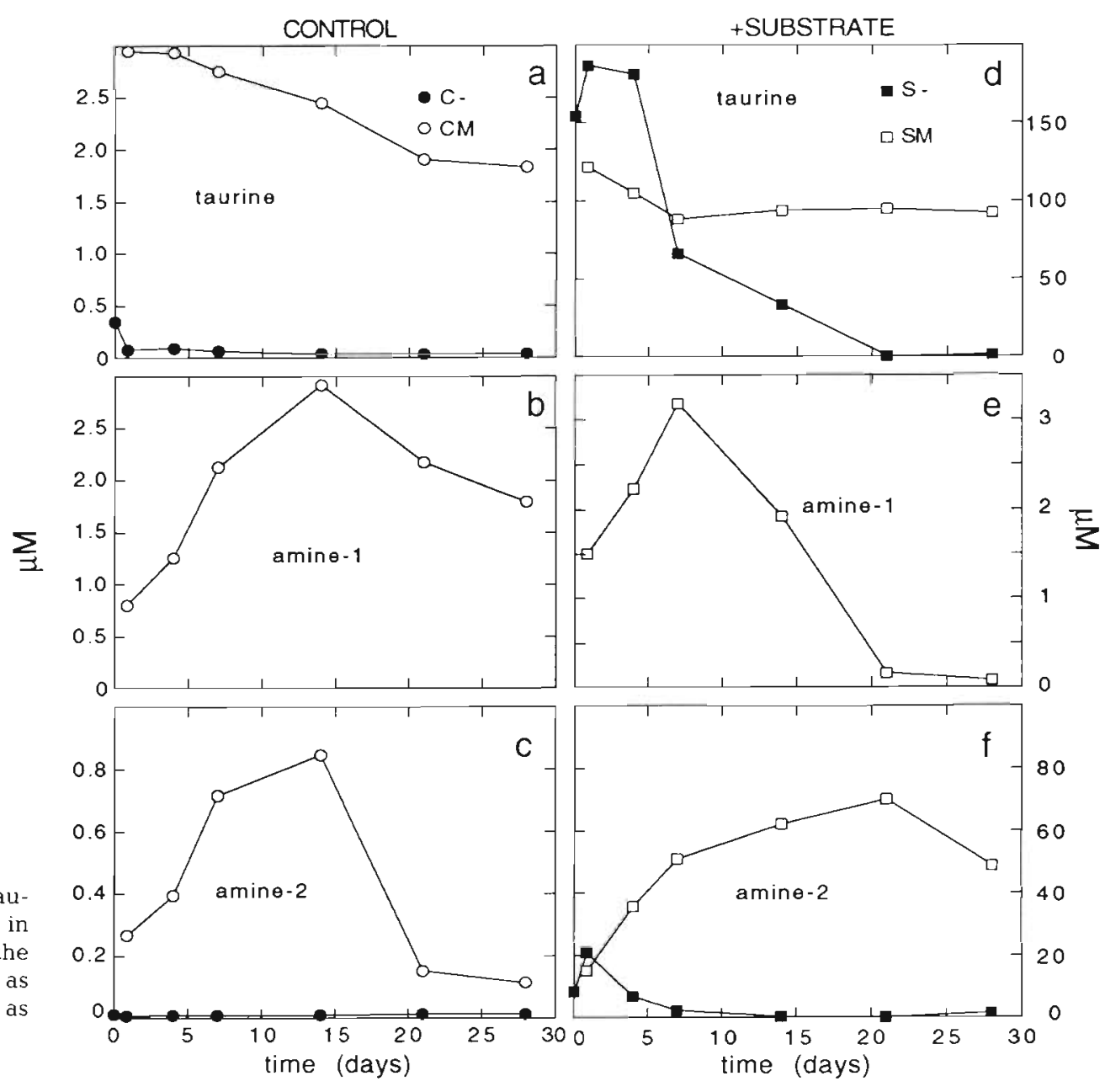

observed. Burdige (1989) found a 13 to $20 \%$ contribution by sulphate-reducing bacteria to $\mathrm{NH}_{4}{ }^{+}$production, whereas Jacobsen et al. (1987) found a higher $\mathrm{NH}_{4}{ }^{+}$ production in the presence of molybdate. Most studies (e.g. Christensen \& Blackburn 1980, Burdige \& Martens 1988, Burdige 1991) have implied that DFAAs are fermented (and deaminated) rather than utilized directly by sulphate-reducing bacteria.

The lower $\mathrm{NH}_{4}{ }^{+}$production in $\mathrm{S}$ - compared to the estimated production was possibly due to $\mathrm{NH}_{4}{ }^{+}$assimilation by sulphate-reducing bacteria when DFAA were mineralized and a high carbon concentration was available (Blackburn 1980, Keil \& Kirchman 1991). Keil \& Kirchman (1991) reported that a considerable part (50 to $88 \%$ ) of the bacterial $\mathrm{N}$-demand was met by $\mathrm{NH}_{4}{ }^{+}$even when DFAA were utilized, and that addition of a readily degradable DOC source would increase this assimilation. In the present experiment there was a large amount of acetate in the substrate giving a pore water (Day 4) concentration of $1.8 \mu \mathrm{mol}$ $\mathrm{cm}^{-3}$, all of which was used. This could have accounted for the incorporation of ca $120 \mathrm{nmol} \mathrm{cm}{ }^{-3} \mathrm{NH}_{4}{ }^{+}$into bacterial biomass at a carbon assimilation efficiency of $30 \%$ (Blackburn 1980). From C-, and unpublished results from other non-inhibited sediments, we found the estimated $\mathrm{NH}_{4}{ }^{+}$production rate to be 92 to $105 \%$ of the measured $\mathrm{NH}_{4}{ }^{+}$production rate.

Amino acid carbon ( $\mathrm{C}: \mathrm{N}=4$ ) could have contributed $952 \mathrm{nmol} \mathrm{cm}{ }^{-3} \mathrm{~d}^{-1}$ to the $\mathrm{TCO}_{2}$ pool in $\mathrm{S}-$. The actual rate of $\mathrm{TCO}_{2}$ production was $1642 \mathrm{nmol} \mathrm{cm} \mathrm{cm}^{-3} \mathrm{~d}^{-1}$ indicating that $42 \%$ of the carbon originated from nonamino sources in the substrate, possibly from acetate as discussed previously.

In conclusion, there is good evidence that sulphatereducing bacteria were involved in the degradation of amino- $\mathrm{N}$ in sediment with high sulphate-reducing activity, and it is probable that amino- $\mathrm{N}$ was the main nitrogen source for $\mathrm{NH}_{4}{ }^{+}$production possibly with urea as an intermediate (Pedersen et al. 1993). The sulphate reduction rates were 763 and $99 \mathrm{nmol} \mathrm{cm} \mathrm{cm}^{-3} \mathrm{~d}^{-1}$ in Sand $\mathrm{C}$ - respectively, corresponding to 86 and $76 \%$ of net $\mathrm{CO}_{2}$ production. Incubation of substrate without molybdate gave 4.2 times the rate of $\mathrm{NH}_{4}{ }^{+}$production and 4.5 times the rate of amino acid turnover, com- 
pared to the molybdate-inhibition incubations (corrected for accumulated amino-N; Table 1). The control sediment had a much lower activity and little $\mathrm{NH}_{4}{ }^{+}$ accumulated, but there was a 3.1-fold difference in amino- $N$ turnover between the non-inhibited and inhibited incubation (corrected for accumulated amino- $\mathrm{N}$, Table 1). However the rates of $\mathrm{NH}_{4}{ }^{+}$production were so low that they could not be accurately measured

Acknowledgements. This work was supported by the Carlsberg Foundation (L.S.H.).

\section{LITERATURE CITED}

Blackburn, T. H. (1980). Seasonal variations in the rate of organic- $\mathrm{N}$ mineralization in anoxic marine sediments. In: Biogéochimie de la matière organique a l'interface eausédiment marin. Edition du CNRS, Paris, p. 173-183

Botte, II. $i^{\prime}$. (1992). Regulation of $\mathrm{C}_{1}$-metabolism in the methanotrophic bacterium Methylococcus capsulatus. Ph.D. dissertation, University of Odense

Burdige, D. J. (1989). The effect of sediment slurrying on microbial processes, and the role of amino acids as substrates for sulfate reduction in anoxic marine sediments. Biogeochemistry 8: 1-23

Burdige, D. J. (1991). Microbial processes affecting alanine and glutamic acid in anoxic marine sediments. FEMS Microbiol. Ecol. 85: 211-233

Burdige, D. J., Martens, C. S. (1988). Biogeochemical cycling in an organic-rich coastal marine basin. 10. The role of amino acids in sedimentary carbon and nitrogen cycling Geochim. Cosmochim. Acta. 52: 1571-1584

Burdige, D. J., Martens, C. S. (1990). Biogeochemical cycling in an organic-rich coastal marine basin. 11. The sedimentary cycling of dissolved, free amino acids. Geochim. Cosmochim. Acta 54: 3033-3052

Christensen, D., Blackburn, T. H. (1980). Turnover of tracer $\left({ }^{14} \mathrm{C},{ }^{3} \mathrm{H}\right.$ labelled) alanine in inshore marine sediments. Mar. Biol. 58: $97-103$

Hansen, L. S., Blackburn, T. H. (1991). Aerobic and anaerobic mineralization of organic material in marine sediment microcosms. Mar. Ecol. Prog. Ser. 75: 283-291

Hansen, L. S., Blackburn, T. H. (1992). Effect of algal bloom deposition on sediment respiration and fluxes. Mar. Biol. 112 : $147-152$

Hedges, J. I., Hare, P. E. (1987). Amino acid adsorption by clay

This article was submitted to the editor minerals in distilled water. Geochim. Cosmochim. Acta 51: 255-259

Henrichs, S. M., Farrington, J. W. (1987). Early diagenesis of amino acids and organic matter in two coastal marine sediments. Geochim. Cosmochim. Acta 51 1-15

Holmer, M., Kristensen, E. (1992). Impact of marine fish cage farming on metabolism and sulfate reduction of underlying sediment. Mar. Ecol. Prog. Ser. 80: 191-201

Jacobson, M. E., Mackin, J., Capone, D. G. (1987). Ammonium production in sediments inhibited with molybdate: implications for the sources of ammonium in anoxic marine sediments. Appl. environ. Microbiol. 53: 2435-2439

Keil, R. G., Kirchman, D. L. (1991). Contribution of dissolved free amino acids and ammonium to the nitrogen requirements of heterotrophic bacterioplankton. Mar. Ecol. Prog Ser. 73: 1-10

Lindroth, P., Mopper, K. (1979). HPLC determination of subpicomole amounts of amino acids by precolumn fluorescence derivatization with o-phthaldialdehyde. Analyt. Chem 51: 1667-1674

Lund, B. Aa., Blackburn, T. H. (1989). Urea tumover in a coastal marine sediment measured by a ${ }^{14} \mathrm{C}$-urea short-time incubation. J. microbılol. Meth. 9: 297-308

Mopper, K., Dawson, R. (1986). Determination of amino acids in sea water - recent chromatographic developments and future directions. Sci. total Environ. 49: 115-131

Oremland, R. S., Capone, D. G. (1987). Use of 'specific' inhibitors in biogeochemistry and microbial ecology. In: Marshall, K. C. (ed.) Advances in microbial ecology, Vol. 10. Plenum Press, London, p. 285-383

Parkes, R. J., Gibson, G. R., Mueller-Harvey, I., Buckingham, W. J., Herbert, R. A. (1989). Determination of the substrates for sulphate-reducing bacteria within marine and estuarine sediments with different rates of sulphate reduction. J. gen. Microbiol. 135: 175-187

Pedersen, H., Lomstein, B. Aa., Blackburn, T. H. (1993). Evidence for bacterial urea production in marine sediments. FEMS Microbiol. Ecol. 12: 51-59

Smith, R. L., Klug, M. J. (1981). Electron donors utilized by sulfate-reducing bacteria in eutrophic lake sediments. Appl. environ. Microbiol. 42: 116-121

Solórzano, L. (1969). Determination of ammonium in natural waters by the phenolhypochiorite method. Limnol. Oceanogr. 14: 799-801

Sugai, S. F., Henrichs, S. M. (1992). Rates of amino acid uptake and mineralization in Resurrection Bay (Alaska) sediments. Mar. Ecol. Prog. Ser. 88: 129-141

Talling, F. (1973). The application of some electrochemical methods to the measurement of photosynthesis and respiration in fresh water. Freshwat. Biol 3: 335-362

Manuscript first received: July 5, 1993

Revised version accepted: September 17, 1993 